\title{
Dominika Kołodziej
}

Uniwerystet Ekonomiczny w Katowicach

e-mail: dominika.kolodziej@ue.katowice.pl

ORCID: 0000-0003-4118-6502

\section{MIEJSCE AUDYTU WEWNĘTRZNEGO I KONTROLI WEWNĘTRZNEJ W SYSTEMIE KONTROLI ZARZĄDCZEJ JST W POLSCE}

\author{
DOI: $10.15611 /$ pn.2021.3.06 \\ JEL Classification: H83, M42
}

\section{(C) 2020 Dominika Kołodziej}

Praca opublikowana na licencji Creative Commons Uznanie autorstwa-Na tych samych warunkach 4.0 Międzynarodowe (CC BY-SA 4.0). Skrócona treść licencji na https://creativecommons.org/licenses/by-sa/4.0/deed.pl

Cytuj jako: Kołodziej, D. (2021). Miejsce audytu wewnętrznego i kontroli wewnętrznej w systemie kontroli zarządczej jst w Polsce. Prace Naukowe Uniwersytetu Ekonomicznego we Wroctawiu, 65(3).

\begin{abstract}
Streszczenie: Przedmiotem artykułu jest analiza funkcjonowania i próba umiejscowienia audytu wewnętrznego i kontroli wewnętrznej w systemie kontroli zarządczej jednostek samorządu terytorialnego (jst) w Polsce. Celem jest wyjaśnienie pojęcia kontroli zarządczej w jst oraz wskazanie obszarów działania audytora wewnętrznego oraz kontroli wewnętrznej w kontekście zapisów ustawy o finansach publicznych (dalej: uofp). Dokonanie próby umiejscowienia tych komórek w strukturze organizacyjnej jst oraz próby ukazania wspólnych obszarów ich działania stanowi cel badawczy publikacji. Jako metodykę analizy zagadnienia zastosowano badania literaturowe, przegląd regulacji prawnych i źródeł internetowych. Oparto się przede wszystkim na literaturze przedmiotu. Przedstawiona w artykule charakterystyka systemu kontroli zarządczej z ważnymi jej elementami, takimi jak: audyt wewnętrzny czy kontrola wewnętrzna, stanowi usystematyzowanie wiedzy w tym zakresie.
\end{abstract}

Słowa kluczowe: audyt wewnętrzny, kontrola wewnętrzna, system kontroli zarządczej, jednostka samorządu terytorialnego.

\section{Wstęp}

Kontynuując rozważania dotyczące poprawy funkcjonowania jednostek samorządu terytorialnego i praktycznych rozwiązań zmierzających do jej osiągnięcia (Kołodziej, 2019, s. 36-43, 2020, s. 100-108), podjęto próbę umiejscowienia audytu we- 
wnętrznego i kontroli wewnętrznej w całym systemie kontroli zarządczej w tych organizacjach. Tematyka funkcjonowania audytu wewnętrznego jst jest powiązana z pojęciem kontroli wewnętrznej, ściśle współpracującej z nim w ramach całego systemu kontroli zarządczej. Wyjaśnienia wymaga również zagadnienie odróżnienia pojęcia kontroli wewnętrznej (tej instytucjonalnej) od terminu kontroli funkcjonalnej i samooceny.

\section{System kontroli zarządezej w jst}

Kierownicy jednostek samorządu terytorialnego zostali zobligowani do zapewnienia funkcjonowania adekwatnej, skutecznej i efektywnej kontroli zarządczej w kierowanych przez siebie instytucjach. Zgodnie z zapisami ustawy o finansach publicznych kontrola zarządcza w jednostkach samorządu terytorialnego stanowi „ogół działań podejmowanych dla zapewnienia realizacji celów w sposób zgodny z prawem, efektywny, oszczędny, adekwatny, skuteczny i terminowy" (Ustawa z dnia 27 sierpnia..., 2009, art. 68) we wszystkich jej aspektach funkcjonowania i warunkach działania. System kontroli zarządczej wpisuje się w założenia koncepcji i reformy administracji publicznej zwanej New Public Management (Młodzik, 2015, s. 185). Koncepcja ta miała za zadanie poprawę jakości zarządzania w sektorze publicznym i miała być alternatywą dla klasycznej administracji publicznej (Czarnecki, 2011, s. 16). Reforma New Public Management, zwana inaczej menedżerskim zarządzaniem publicznym (Pabis, 2017 s. 13), dążyła do tego, by w sposób trwały zaadaptować „mechanizmy rynkowe oraz metody i techniki zarządcze szeroko wykorzystywane w sektorze prywatnym oraz nastawić administrację na skuteczność działania, ekonomiczną wydajność, jakość oraz zorientowanie na wyniki” (Młodzik, 2015, s. 185). Cele kontroli zarządczej w jst to zapewnienie przede wszystkim:

1) zgodności działalności z przepisami prawa oraz procedurami wewnętrznymi;

2) skuteczności i efektywności działania, w szczególności przez system kontroli instytucjonalnej i zewnętrznej pozwalający na dokonywanie niezbędnych zmian w ocenianych obszarach;

3) wiarygodności sprawozdań, w tym finansowych;

4) ochrony zasobów w szczególności przez zabezpieczenie wszystkich zasobów jst i udostępnianie ich tylko osobom upoważnionym;

5) przestrzegania i promowania zasad etycznego postępowania;

6) efektywności i skuteczności przepływu informacji;

7) zarządzania ryzykiem, w szczególności przez identyfikację, analizę ryzyka związanego z celami i zadania jst (Ustawa z dnia 27 sierpnia..., 2009, art. 68 ust. 2).

Kontrola zarządcza w jst wykonywana jest przez stosowanie elementów standardu, takich jak:

1) funkcjonowanie środowiska wewnętrznego,

2) określenie celów realizowanych zadań oraz zarządzanie ryzykiem,

3) tworzenie i funkcjonowanie mechanizmów kontroli, 
4) efektywna komunikacja i informacja zewnętrzna i wewnętrzna,

5) monitorowanie i ocena.

Na system kontroli zarządczej składa się całość regulacji zewnętrznych i wewnętrznych oraz wytycznych obowiązujących w jst. Odpowiedzialność w ramach systemu kontroli zarządczej ponoszą kierujący jednostkami samorządu, którzy potrzebują zapewnienia, że wszyscy pracownicy znają i rozumieją cele ogólne jst oraz postawione przed nimi zadania wynikające $\mathrm{z}$ tych celów. Ponadto zarządzający jst chcą uzyskać zapewnienie, że:

1) podejmowane działania mające doprowadzić do realizacji celów i zadań są skuteczne i zapewniają uzyskiwanie najlepszych efektów z ponoszonych nakładów, natomiast rodzaje ryzyka związanego z realizacją celów są na bieżąco identyfikowane, zarządzane i monitorowane,

2) działania podległych komórek organizacyjnych pozostają w zgodzie z przepisami prawa, zasadami przyjętymi w jednostce (procedurami) oraz ze standardami kontroli zarządczej,

3) zasoby są zużywane oszczędnie i w sposób przynoszący pożytek,

4) plany, programy, zamierzenia oraz wynikające z nich cele i zadania są osiągane w planowanym terminie,

5) dane i informacje publikowane lub udostępniane wewnętrznie czy na zewnątrz są dokładne, wiarygodne i aktualne, a przepływ informacji jest efektywny i skuteczny,

6) zasoby organizacji, wliczając w to pracowników i systemy informatyczne, są dostatecznie zabezpieczone i nadzorowane.

Zapewnienie, o którym mowa, zarządzający jst otrzymują między innymi od audytora wewnętrznego, który dokonuje oceny funkcjonowania kontroli zarządczej w badanej jednostce, a także uzyskują je przez wyniki kontroli dokonanej przez instytucjonalną kontrolę wewnętrzną.

\section{Audyt wewnętrzny w jst}

Audyt wewnętrzny jest niezależną, obiektywną działalnością zapewniającą i doradczą, której cele stanowią zwiększenie wartości i poprawa funkcjonowania organizacji. Pomaga on organizacji w osiągnięciu jej celów przez zastosowanie systematycznego, zdyscyplinowanego podejścia do oceny i poprawy skuteczności procesów zarządzania ryzykiem, kontroli i zarządzania. Czynności audytu wewnętrznego są przeprowadzane w różnych środowiskach prawnych i kulturowych, w organizacjach różniących się celem, wielkością i strukturą, a także przez osoby z organizacji lub spoza niej (Standards..., 2001, s. 1). Jednym z rodzajów instytucji polskich, w których funkcjonuje audyt wewnętrzy jako element obligatoryjny lub wspomagający kierownictwo, są jednostki samorządu terytorialnego. Audyt wewnętrzny w jst jest (obok instytucjonalnej kontroli wewnętrznej, samokontroli, kontroli funkcjonalnej i instytucjonalnej kontroli zewnętrznej - por. rys. 1) jednym z elementów kontroli zarządczej. Kierownicy jst odpowiadają za „ustanowienie komórki audytu we- 


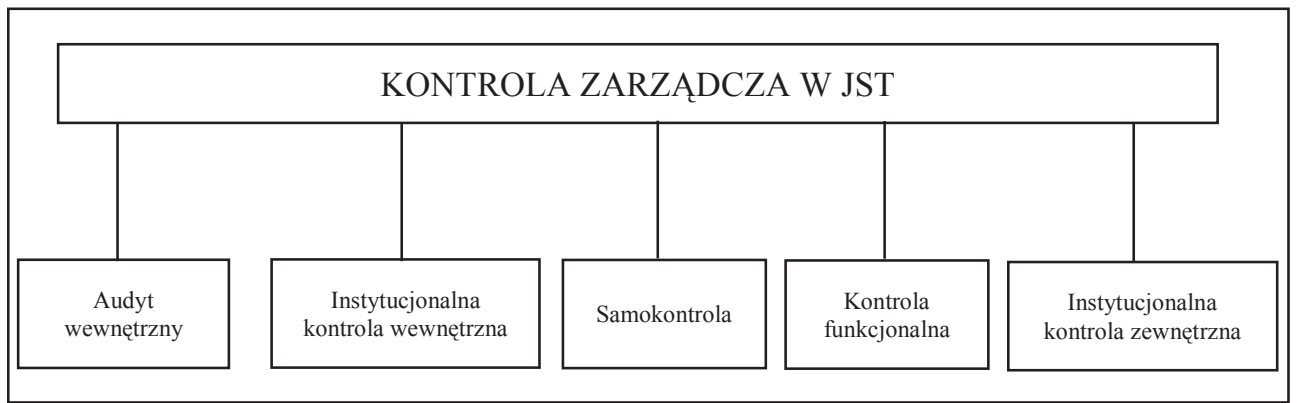

Rys. 1. Elementy kontroli zarządczej w jst

Źródło: opracowanie własne.

wnętrznego - niezależnej od pozostałych komórek organizacji” (Emerling, 2015, s. 91). Audyt wewnętrzny ma „przysporzyć dodatkowych wartości, usprawnić działalność operacyjną jednostki i przyczynić się do poprawy jej działania" (Szczepankiewicz, 2017, s. 12). Rolą audytu wewnętrznego jest niezależna ocena funkcjonowania kontroli zarządczej dla zarządzających jst. Audytor winien również doradzać zarządzającym (Winiarska, 2017, s. 55). Sprawując funkcje doradcze, audytor odgrywa rolę mędrca, który służy ${ }^{1}$ radą (Skoczylas i Kulczyńska, 2017, s. 33). Audyt wewnętrzny nie powinien zatem mieć bezpośredniego wpływu na zarządzanie jednostką, zwłaszcza że efektem jego działania mają być obiektywne zalecenia skierowane do odpowiedzialnych za badane przez niego obszary i dotyczące w każdym przypadku elementów kontroli zarządczej. Audytor wewnętrzny nazywany jest przez samych zainteresowanych nawigatorem albo aniołem (Kabalski i Grzesiak, 2017, s. 16). Audyt jest także podstawą dobrego zarządzania jednostkami samorządu terytorialnego. Przez obiektywną ocenę zapewnia kierownika jednostki o tym, że środki publiczne są celowo, gospodarnie i skutecznie wydatkowane. Działalność audytora wewnętrznego w jst wspiera zarządzającego w nadzorze i przeglądzie procesów. Audyt wewnętrzny jest pojmowany w literaturze przedmiotu także jako „kontrola głównie profilaktyczna" (Fleszer, 2018, s. 90) czy zapobiegawcza.

\section{Kontrola wewnętrzna $w$ jst}

Kontrola wewnętrzna $\mathrm{w}$ jst jest pojęciem bardzo dobrze znanym i stosowanym w polskiej administracji publicznej, w tym w szczególności w instytucjach samorządowych. Ustawa o finansach publicznych z 2009 r. nie podaje wprost definicji kontroli, ale posługuje się wyjaśnieniem, stosując w odniesieniu do niej następujące określenia:

${ }^{1}$ Służyć ma nie tylko audytor, ale ma to czynić również cała administracja. Słowo ,administracja” pochodzi od łacińskiego ministrare, oznaczającego służbę, służenie, zaś termin ad ministro oznacza kierować, rządzić. 
- kontrola procesów związanych zgromadzeniem i rozdysponowaniem środków publicznych oraz gospodarowaniem mieniem,

- kontrola gospodarki finansowej,

- wstępna kontrola,

- bieżąca kontrola dochodów i wydatków,

- kontrola wykonania zadania,

- ogólna kontrola realizacji dochodów i wydatków oraz przychodów i rozchodów budżetu państwa,

- nadzór i kontrola nad całością gospodarki finansowej.

Komórki kontroli wewnętrznej (rozumiane jako instytucjonalna kontrola wewnętrzna) funkcjonują w urzędach obok komórek audytu wewnętrznego.

Wewnętrzna kontrola instytucjonalna sprawowana jest przez specjalistę lub/i specjalistów ds. kontroli. Natomiast innymi formami kontroli są samokontrola oraz kontrola funkcjonalna, realizowane przez wszystkich pracowników jednostki organizacyjnej w ramach ich obowiązków służbowych i na swoich stanowiskach pracy (Ampuła, 2014, s. 20). Samoocena powinna być procesem, w którym uczestniczą wszyscy pracownicy i kierownictwo jednostki (w praktyce samorządowej tak się zazwyczaj dzieje). Narzędziem do samooceny, stosowanym najczęściej w jst, jest ankieta samoceny. Może ona mieć szczególne znaczenie w tych jednostkach samorządu terytorialnego, w których nie funkcjonuje audyt wewnętrzny (gdyż nie ma obowiązku ustawowego - por. zapisy uofp) lub zasoby audytu nie są wystarczające.

\section{Miejsce audytu wewnętrznego i kontroli wewnętrznej w systemie kontroli zarządczej jst}

Podstawową rolą audytu wewnętrznego jest stworzenie wartości dodanej w organizacji przez niezależną, profesjonalną i systematyczną ocenę systemu kontroli zarządczej. Audyt wewnętrzny jest narzędziem jej monitorowania, profesjonalnej oceny oraz źródłem rekomendacji usprawniających. Jednocześnie audyt wewnętrzny cechują obiektywność i niezależność, dlatego organizacja audytu wewnętrznego $\mathrm{w}$ jednostce powinna być w jak największym stopniu usamodzielniona w stosunku do pozostałych komórek. Natomiast kontrola zarządcza swoim zasięgiem obejmuje całą organizację. Celem kontroli zarządczej jest zatem zapewnienie realizacji celów i zadań, zaś celem audytu wewnętrznego są ocena tej kontroli oraz czynności doradcze. $Z$ tego powodu audytor wewnętrzny nie powinien uczestniczyć w budowaniu systemu kontroli zarządczej i zarządzaniu, ponieważ mogłoby to rzutować na obiektywność jego oceny. Nie można też próbować zastąpić kontroli zarządczej audytem wewnętrznym czy kontrolą wewnętrzną, ponieważ audytor wewnętrzny i specjalista ds. kontroli wewnętrznej, w przeciwieństwie do kierownika jednostki, 
nie posiadają odpowiednich umocowań i uprawnień w tym zakresie. Ponadto obydwa te stanowiska nie zostały ustawowo wyposażone w kompetencje władcze nad procesami zarządczymi w jednostce. Natomiast skuteczny audyt wewnętrzny powinien być narzędziem monitorowania i oceny kontroli zarządczej. Podsumowując, należy stwierdzić, że audyt wewnętrzny i kontrola wewnętrzna stanowią nierozerwalną podstawę adekwatnego, skutecznego i efektywnego zarządzania celami i zadaniami $\mathrm{w}$ jednostkach samorządu terytorialnego. W literaturze przedmiotu można się również spotkać ze stwierdzeniem, że „działania podejmowane w ramach audytu wewnętrznego dotyczą analizy i oceny efektywności i skuteczności innych kontroli, ustanowionych przez kierownika jednostki w celu zapewnienia prawidłowego zarządzania, minimalizacji kosztów funkcjonowania jednostki oraz uzyskania jak najlepszych efektów z jej funkcjonowania" (Ciak i Voss, 2017, s. 237). W praktyce działania audytu wewnętrznego i wewnętrznej kontroli instytucjonalnej dokonywane $\mathrm{w}$ ramach oceny kontroli zarządczej w jst powinny się uzupełniać. W tym celu powinny być odpowiednio skoordynowane. W jaki sposób zorganizować działania tych komórek organizacyjnych, by właściwe spełniały swoje funkcje? Otóż: w jednostkach samorządu terytorialnego nadrzędną komórką będzie zawsze komórka audytu wewnętrznego, która może objąć badaniem obszar, którym zajmuje się komórka kontroli wewnętrznej. Natomiast działania i świadczona na rzecz kierownika jst praca audytu wewnętrznego i kontroli wewnętrznej winny być spójne. Może to nastąpić między innymi przez podejmowanie badań (przez audyt i kontrolę) obszarów działalności jednostki, które się uzupełniają. W rezultacie kierownik otrzyma ocenę funkcjonowania całej jednostki. Audytor funkcjonuje wyżej w strukturze organizacyjnej niż inspektor czy specjalista ds. kontroli. Wynika to między innymi z zapisów Rozporządzenia Rady Ministrów z dnia 15 maja 2018 r. w sprawie wynagradzania pracowników samorządowych. Zgodnie z zapisami tego aktu prawnego audytor jest traktowany na równi z głównym księgowym w jst, znajdując miejsce wśród urzędniczych stanowisk kierowniczych. Należy do kadry zarządzającej, natomiast kontroler wewnętrzny spełnia funkcje operacyjne i zajmuje stanowisko podinspektora, inspektora, specjalisty lub głównego specjalisty. Komórki kontroli wewnętrznej dostarczają informacji na temat wielu obszarów działania jst, która może być wykorzystana do oceny funkcjonowania elementów kontroli zarządczej. Jednym z głównych zadań kontroli wewnętrznej jest badanie gospodarki finansowej jst pod względem kryterium zgodności z przepisami prawa i procedurami wewnętrznymi, wiarygodności sprawozdań i ochrony zasobów.

Funkcjonowanie audytu wewnętrznego i kontroli wewnętrznej w jednostce samorządu terytorialnego według wybranych kryteriów działania zostało przedstawione w tabeli 1.

Kontrola nastawiona jest również na pozyskiwanie informacji o nieprawidłowościach. Dobrze jest, gdy komórki kontroli tworzą plany kontroli na podstawie 


\begin{tabular}{|c|c|c|c|c|c|c|}
\hline 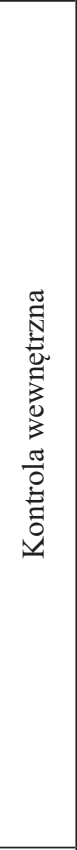 & 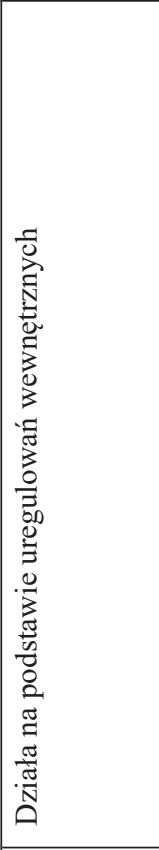 & 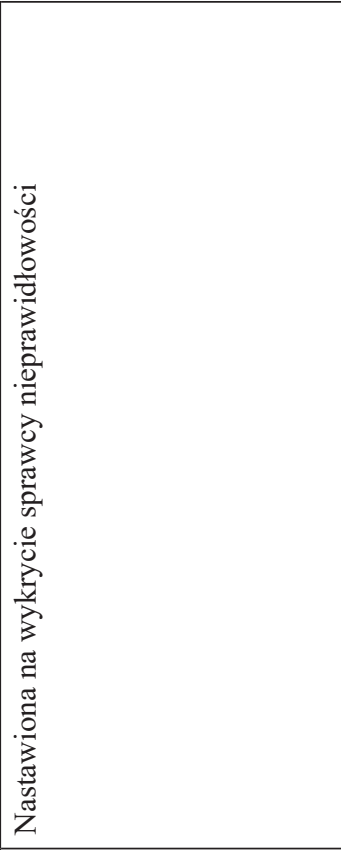 & 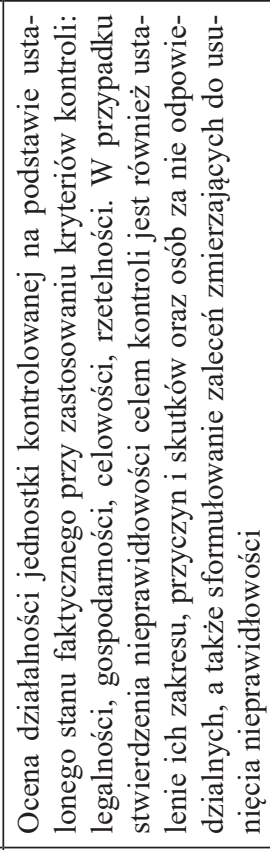 & 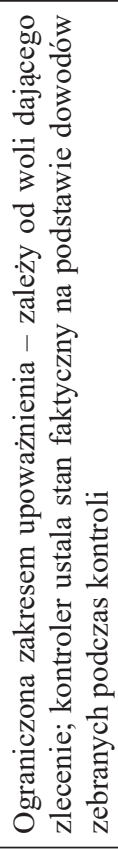 & 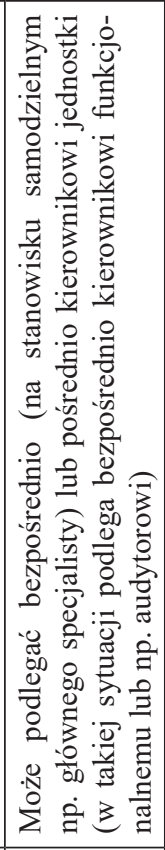 & 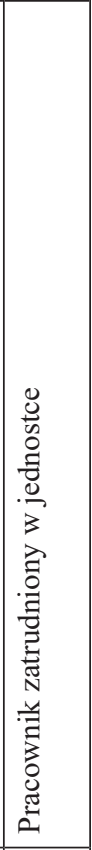 \\
\hline 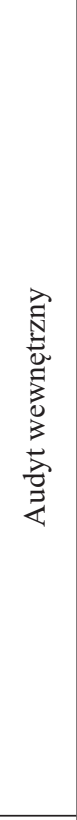 & 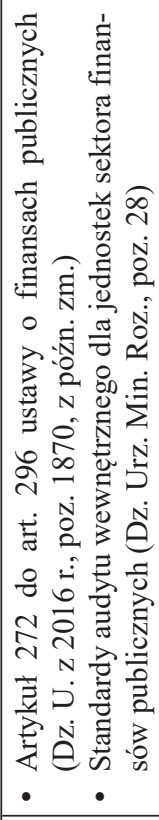 & 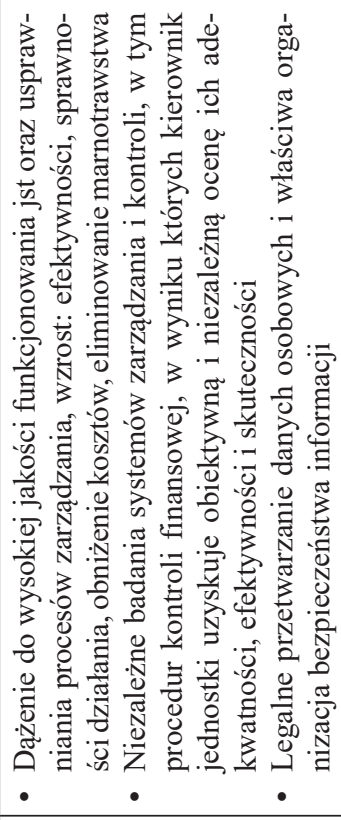 & 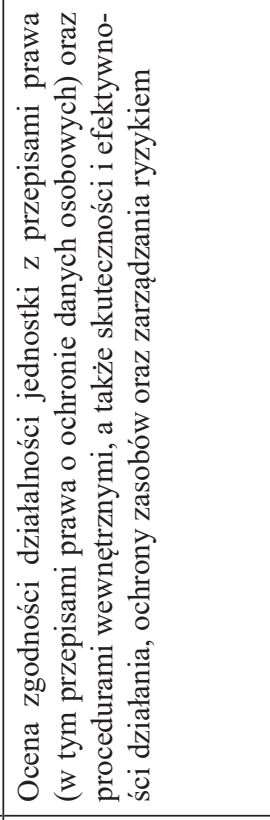 & 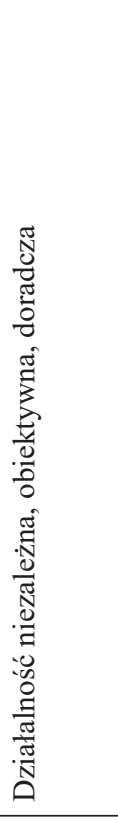 & 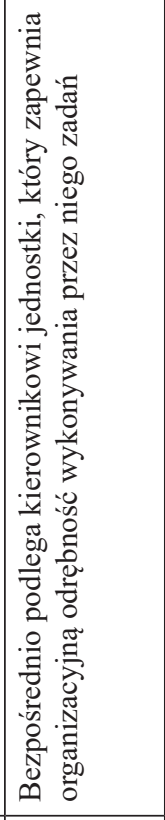 & 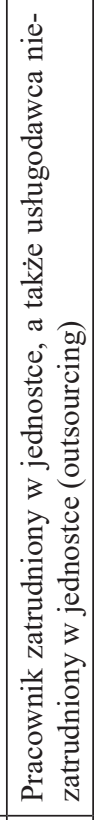 \\
\hline 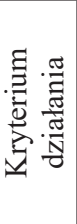 & 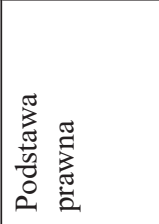 & 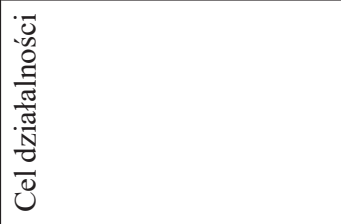 & 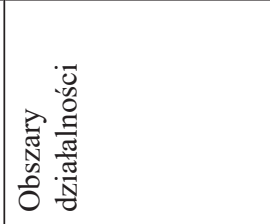 & 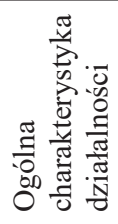 & 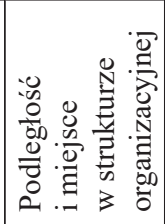 & (: \\
\hline
\end{tabular}


analizy ryzyka. Kontrola wewnętrzna może zdobywać informacje, stosując narzędzia i techniki ich pozyskiwania podobne do wykorzystywanych podczas audytu wewnętrznego. Ponadto instytucjonalna kontrola wewnętrzna przeprowadza badanie jednostek podległych i nadzorowanych, które rzadziej podlegają czynnościom audytowym ze strony audytu wewnętrznego jednostki nadrzędnej.

\section{Zakończenie}

Audyt wewnętrzny i kontrola wewnętrzna stanowią dwa odrębne elementy kontroli zarządczej w jst. Prowadzone w sposób rzetelny i efektywny dają kierownikom gwarancję, że system kontroli zarządczej w ich jednostkach działa prawidłowo. Tworzenie komórki ds. kontroli wewnętrznej, w przeciwieństwie do zatrudnienia audytora wewnętrznego, nie wynika bezpośrednio z przepisów prawa. Natomiast i jedno, i drugie rozwiązanie jest odpowiedzią na konieczność zapewnienia kierownika, że działania jednostki, którą kieruje, są legalne, gospodarne, celowe i rzetelne. W szczególności audyt wewnętrzny ocenia zgodność działalności jednostki z przepisami prawa (w tym przepisami prawa o ochronie danych osobowych) oraz procedurami wewnętrznymi, a także dokonuje oceny skuteczności i efektywności działania, ochrony zasobów oraz zarządzania ryzykiem. Kontrola wewnętrzna jest nastawiona na zbadanie i ocenę działalności jednostki kontrolowanej na podstawie ustalonego stanu faktycznego przy zastosowaniu odpowiednich kryteriów kontroli. Skoordynowana działalność audytu i kontroli wewnętrznej będzie podstawą do skutecznego i sprawnego zarządzania jst. W jednostkach samorządu terytorialnego koordynacja tych działań może zostać osiągnięta przez zaprojektowanie odpowiednich struktur organizacyjnych, w których audyt wewnętrzny i/lub audytorzy wewnętrzni i kontroler wewnętrzny i/lub kontrolerzy wewnętrzni będą pracować w jednej komórce organizacyjnej (np. w jednym biurze, referacie czy wydziale audytu i kontroli wewnętrznej). Nadrzędność audytu wewnętrznego w stosunku do kontroli wewnętrznej przejawia się w funkcji kierownika takiej komórki, którym będzie audytor wewnętrzny. Takie rozwiązanie wpłynie również pozytywnie na proces komunikowania się między audytem a kontrolą wewnętrzną (np. skróci ten proces czy zmniejszy liczbę zakłóceń). Efektywne funkcjonowanie audytu wewnętrznego i kontroli wewnętrznej $\mathrm{w}$ jednostkach samorządu terytorialnego oddziałuje na racjonalność i skuteczność wydatkowania środków publicznych, czyli tych środków, które pochodzą z dochodów publicznych, budżetu państwa, jednostek samorządowych oraz źródeł zagranicznych (Ustawa z dnia 27 sierpnia..., 2009, art. 5).

\section{Literatura}

Ampuła, D. (2014). Kontrola i audyt wewnętrzny w jednostce organizacyjnej. Biuletyn Wojskowego Instytutu Technicznego Uzbrojenia, 132(4). Pobrano 22 lutego $2021 \mathrm{z}$ http://www.witu.mil.pl/ www/biuletyn/ptu_2014/132/17.pdf 
Ciak, J. i Voss, G. (2017). Rola audytu wewnętrznego w sektorze publicznym i prywatnym - wyniki badań w zakresie problemów wdrażania i korzyści z wykorzystania audytu wewnętrznego. Studia Prawno-Ekonomiczne, (CIV).

Czarnecki, K. (2011). Idee i praktyki Nowego Zarządzania Publicznego. Zarządzanie Publiczne, 1(15). Pobrano z http://bazhum.muzhp.pl/media//files/Zarzadzanie_Publiczne/Zarzadzanie_Publiczne-r2011-t-n15_(1)/Zarzadzanie_Publiczne-r2011-t-n15_(1)-s5-19/Zarzadzanie_Publiczne-r2011-t-n15 (1)-s5-19.pdf

Emerling, I. (2015). Rola audytu w zarządzania jednostką - aspekt praktyczny. Studia Ekonomiczne. Zeszyty Naukowe Uniwersytetu Ekonomicznego w Katowicach, (240).

Fleszer, D. (2018). Audyt wewnętrzny w jednostkach sektora finansów publicznych - wybrane elementy. Roczniki Administracji i Prawa, (XVIII(2)), 81-94.

Kabalski, P. i Grzesiak, L. (2017). Funkcje audytu wewnętrznego w opinii polskich audytorów. Zeszyty Teoretyczne Rachunkowości, 91(147), 9-20.

Kuc, B. R. (2002). Audyt wewnętrzny, teoria i praktyka. Warszawa: PTM.

Kołodziej, D. (2019). Rola audytora wewnętrznego oraz inspektora ochrony danych osobowych w jednostce samorządu terytorialnego. W: P. Bednarek (red.), Audyt wewnętrzny a ocena ryzyka kondycji ekonomicznej podmiotów gospodarczych i instytucji (s. 36-43). Wrocław: Wydawnictwo Uniwersytetu Ekonomicznego we Wrocławiu.

Kołodziej, D. (2020). Audyt wewnętrzny w jednostce samorządu terytorialnego - komórka wewnętrzna czy firma zewnętrzna? Prace Naukowe Uniwersytetu Ekonomicznego we Wrocławiu, 64(5).

Komunikat Ministra Rozwoju i Finansów z dnia 12 grudnia 2016 r. w sprawie standardów audytu wewnętrznego dla jednostek sektora finansów publicznych (Dz. Urz. Min. Roz., poz. 28)

Komunikat nr 3 Ministra Finansów z dnia 16 lutego 2011 r. w sprawie szczegółowych wytycznych w zakresie samooceny kontroli zarządczej dla jednostek sektora finansów publicznych (Dz. Urz. Min. Fin. nr 2, poz. 11)

Młodzik, E. (2015). Założenia koncepcji New Public Management. Zeszyty Naukowe Uniwersytetu Szczecińskiego, Wspótczesne Problemy Ekonomiczne, (11). doi: 10.18276/wpe.2015.11-17.

Pabis, Ł. (2017). Zrównoważony rozwój w kontekście nowych koncepcji zarządzania publicznego: New Public Management i Public Governance (nowego zarządzania publicznego i zarządzania partycypacyjnego). Zeszyty Naukowe Politechniki Częstochowskiej. Zarządzanie, 2(25), 7-22. Pobrano z http://www.zim.pcz.pl/znwz

Piaszczyk, A. (2017). Audyt a kontrola - porównanie. Studia Ekonomiczne. Zeszyty Naukowe Uniwersytetu Ekonomicznego w Katowicach, (333).

Rozporządzenie Ministra Finansów z dnia 4 września 2015 r. w sprawie audytu wewnętrznego oraz informacji o pracy i wynikach tego audytu (Dz.U. z 2015 r., poz. 1480)

Skoczylas, W. i Kulczyńska, A. (2017). Finansowanie rozwoju jednostki samorządu terytorialnego ze źródeł zewnętrznych jako zadanie doradcze audytu wewnętrznego. Finanse, Rynki Finansowe, Ubezpieczenia, 3(87), 1, 31-41.

Standards of the professional practice of internal auditing. (2001). Internal Auditor, (1).

Szczepankiewicz, E. I. (2017). Jakość audytu wewnętrznego a wartość dodana w jednostkach sektora finansów publicznych. Finanse, Rynki Finansowe, Ubezpieczenia, (3(87)), 1, 111-120.

Tkocz-Wolny, K. (2015). Pojęcie i zakres kontroli zarządczej w jednostkach sektora finansów publicznych. Zeszyty Naukowe Uniwersytetu Szczecińskiego, (855), Finanse, Rynki Finansowe, Ubezpieczenia, 2(74), 547-557. Pobrano z www.wneiz.pl/frfT

Ustawa z dnia 27 sierpnia 2009 r. o finansach publicznych (Dz.U. z 2016 r., poz. 1870, z późn. zm.)

Winiarska, K. (2017). Funkcja doradcza na tle aktualnych i perspektywicznych celów audytu wewnętrznego. Finanse, Rynki Finansowe, Ubezpieczenia, 3(87), 1, 55-64. 


\title{
PLACE OF INTERNAL AUDIT AND INTERNAL CONTROL IN THE MANAGEMENT CONTROL SYSTEM OF THE LOCAL GOVERNMENT UNIT IN POLAND
}

\begin{abstract}
The subject of this article is the analysis of the functioning of internal audit and internal control in the whole system of management control of local government units. The purpose of this article is to indicate the areas of internal audit and internal control in the context of the provisions of the Law on Public Finance. Making an attempt to locate these two positions in the organizational structure of local government units and an attempt to show the common areas of their activity is the research objective of the publication, which, based on the analysis of legal regulations and literature, has been achieved. This proposal is a response to the need for continuous support for the head of the unit by internal audit and internal control, which are very important elements of the whole management system aimed at achieving objectives in a legal, effective, economical, appropriate, efficient and timely manner. Literature research, review of legal regulations and in-ternet sources were used as a methodology of the issue analysis.
\end{abstract}

Keywords: internal auditor, internal control, local government, management control. 